Rumôh

Journal of Architecture - University of Muhammadiyah Aceh

Vol: 11 |No: 1 (2021): June

\title{
REDESAIN ASRAMA HAJI ACEH, TEMA: GREEN ARCHITECTURE
}

Redesign of Aceh Hajj Dormitory, Theme: Green Architecture

\author{
Ahmadi $^{1}$, Aidina $^{2}$ \\ 1) Program Studi Arsitektur, Fakultas Teknik UNMUHA (020396ahmadi@gmail.com) \\ 2) Program Studi Arsitektur, Fakultas Teknik UNMUHA (faiza.aidina@unmuha.ac.id)
}

\begin{abstract}
ABSTRAK
Redesain Asrama Haji Aceh dilatarbelakangi oleh kondisi bangunan yang dirasakan sudah tidak cukup layak untuk memfasilitasi kegiatan yang akan ditampung pada saat layanan operasional musim haji. Beberapa permasalahan terkait bangunan asrama haji adalah kondisi bangunan yang sudah tua dan lembab, kapasitas ruangan yang sudah tidak mencukupi dikarenakan jumlah rombongan haji yang bertambah setiap tahunnya, dan beberapa sarana prasarana yang belum ada pada bangunan dan harus dipenuhi terait syarat operasional layanan. Perancangan ruang luar bangunan juga memerlukan perhatian khusus, seperti mengatur jarak antar bangunan agar sesuai dengan hirarki zonasinya serta penataan parkir yang lebih teratur dan sirkulasi jalur masuk dan keluar yang terarah sehingga tidak menciptakan kemacetan pada saat musim haji. Perencanaan ulang Asrama Haji Aceh berlokasi di jalan T. Nyak Arif, Lingke, Kecamatan Kuta Alam, Banda Aceh. Maksud dari perencanaan ini adalah dapat memberikan kenyamanan bagi calon jamaah haji dengan menyediakan fasilitas yang memadai untuk jamaah yang sesuai dengan kebutuhan dan fungsinya. Klasifikasi Redesain Asrama Haji Aceh merupakan Type Asrama Haji Embarkasi, yaitu Unit Pelaksana Teknis Direktorat Jenderal Penyelenggaraan Haji dan Umrah. Perencanaan ini menerapkan tema Green Architecture dengan memanfaatkan kondisi dan sumber energy alami, menaggapi keadaan tapak pada bangunan dan memperhatikan pengguna bangunan. Analisis yang dipakai dalam bangunan ini yaitu analisis fungsional, analisis tapak dan analisis bangunan. Redesain Asrama Haji Aceh menerapkan pemanfaatan air hujan dan penerapan vertical garden. Luas Lahan 25.300 m2. Bangunan bermassa banyak dan bertingkat rendah, Koefesien Dasar Bangunan (KDB) 151.800 m2 dan luas keseluruhan bangunan 50.600 m2. Redesain Asrama Haji Aceh memiliki 84 kamar dengan kapisitas satu kamar 4 orang. Fasilitas penunjang lainnya adalah kantin, masjid dan pos satpam.
\end{abstract}

Kata-kata kunci: Green Architecture, Jeulingke, Redesain Asrama Haji Aceh.

\section{ABSTRACT}

The redesign of the Aceh Hajj Dormitory was motivated by the condition of the building which was felt to be inadequate to facilitate the activities that would be accommodated during the operational service of the Hajj season. Some of the problems related to the Hajj dormitory building are the condition of the building that is old and damp, the room capacity is not sufficient due to the number of Hajj groups that increase every year, and some infrastructure facilities that do not exist in the building and must be met regarding service operational requirements. The design of the outer space of the building also requires special attention, such as adjusting the distance between buildings to match the zoning hierarchy and more regular parking arrangements and manage entry-exit circulationin order not to make any congestion during the hajj season. The redesign project is located on Jalan T. Nyak Arif, Lingke, Kuta Alam District, Banda Aceh. The redesign intention is to provide comfort and adequate facilities for pilgrims according to their needs and functions. The Classification of the Redesign of the Aceh Hajj Dormitory is a Type of Embarkation Hajj Dormitory, the Technical Implementation Unit of the Directorate General of Hajj and Umrah. This plan applies the theme of Green Architecture by utilizing conditions and natural energy sources, responding to the site conditions of the building and paying attention to building users. The analysis used in this building is functional analysis, site analysis and building analysis. The redesign of the Aceh Hajj Dormitory applies the use of rainwater and the application of a vertical garden. Land area 25,300 m2. High-mass and low-rise buildings, the Building Base Coefficient (KDB) is 151,800 m2 and the total building area is 50,600 m2. The redesign of the Aceh Hajj Dormitory has 84 rooms with a capacity of one room for 4 people. Supporting facilities include canteens, mosques and security posts.

Keywords: Green Architecture, Jeulingke, Redesign, Aceh Hajj Dormitory

\begin{tabular}{lll}
\hline Article History & & \\
\hline Diterima (Received) & $:$ & $17-06-2021$ \\
Diperbaiki (Revised) & $:$ & $29-06-2021$ \\
Diterima (Accepted) & $:$ & $30-06-2021$
\end{tabular}




\section{PENDAHULUAN}

Ibadah haji merupakan rukun Islam kelima yang wajib dilaksanakan oleh setiap orang Islam yang memenuhi syarat istitah, baik secara finansial, fisik, maupun mental. Negara bertanggung jawab atas penyelenggaraan ibadah haji sebagaimana yang diamanatkan dalam Pasal 29 Ayat (2) UndangUndang Dasar Negara Republik Indonesia Tahun 1945, yang menyatakan bahwa Negara menjamin kemerdekaan tiap-tiap penduduk untuk memeluk agamanya masing-masing dan untuk beribadat menurut agama dan kepercayaannya itu.

Fungsi utama dari asrama haji adalah untuk mengakomodasi kebutuhan calon jamaah haji sebelum diberangkatkan dan setelah dipulangkan dari tanah suci. Penggunaan masa operasional Asrama Haji hanya selama 68 hari dari 365 hari yang dimiliki dalam setahun, sehingga walaupun hanya digunakan dalam waktu yang singkat oleh calon jamaah haji akan tetapi penggunaan asrama haji sangat berperan dalam mempersiapkan mental para calon jamaah haji sebelum diberangkatkan ke tanah suci (Makkah). Diluar masa operasional tersebut juga difungsikan pada kegiatan kegiatan lain seperti; resepsi pernikahan, seminar dan penginapan.

Asrama Haji Aceh berdiri pada tahun 1985 yang berada pada JIn. T. Nyak Arif No. 128 Banda Aceh dengan jumlah gedung 9 Unit dan 7 Unit gedung pendukung dengan kapasitas daya tampung sekitar 450 orang. Dari hasil survey yang di lakukan ada beberapa masalah yang terjadi di asrama haji Aceh yang telah beroperasional selama kurang lebih 31 tahun terakir. Beberapa masalah yang diketahui dari segi fasilitas bangunan ini tidak mendukung operasional dengan baik seperti; kenyamanan difable, dan penggunaan ram untuk lansia. kondisi fisik bangunan yang memungkinkan untuk di renovasi dan penataan ruang luar yang tidak terarah.

Menurut data dari laporan penyelenggaraan pemberangkatan dan pemulangan haji embarkasi (BTJ) dari kurun waktu 5 tahun kebelakang di hitung dari tahun 2013-2017, jumlah pengguna asrama haji Aceh (Calon Jamaah Haji) setiap tahunnya mengalami peningkatan rata-rata $1 \%$. Berdasarkan data tersebut, perlu adanya pengembangan fasilitas terkait kapasitas calon jamaah yang bertambah tiap tahunnya maka perlu adanya redesain Asrama Haji Aceh untuk peningkatan fasilitas, seperti; kamar tidur, ruang penerimaan dan fasilitas parkir.

\section{DESKRIPSI LOKASI}

Lokasi perancangan merupakan lahan eksisting Asrama Haji Aceh yaitu di Jalan T.Nyak Arif No.128 Banda Aceh, dengan Luas Lahan: 25,300 m²/ 25,3 $\mathrm{Ha}$.

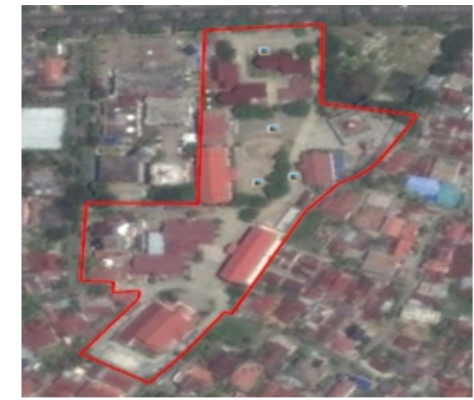

Gambar 1: Lokasi Perancangan

(Sumber: Google map, 2019)

\section{STUDI LITERATUR}

\subsection{Fungsi}

Dalam Pelaksanaan tugas sebagaimana dimaksud dalam pasal (2) dalam UU. RI. No. 13 Tahun 2008 tentang penyelenggaraan ibadah haji, maka Asrama Haji Embarkasi menyelengarakan fungsi yang tertera pada pasal (7) yang berbunyi "Jama'ah Haji berhak memperoleh pembinaan, pelayanan dan perlindungan dalam menjalankan Ibadah Haji, yang meliputi :

1. Pembimbingan manasik haji dan/atau materi lainnya, baik di tanah air, di perjalanan maupun di Arab Saudi;

2. Pelayanan Akomodasi, konsumsi, Transportasi, dan Pelayanan Kesehatan yang memadai, baik di tanah air, selama di perjalanan maupun di Arab Saudi;

3. Perlindungan sebagai Warga Negara Indonesia;

4. Penggunaan Paspor Haji dan Dokumen lainnya yang diperlukan untuk pelaksanaan Ibadah Haji, dan

5. Pemberian kenyamanan Transportasi dan pemondokan selama di tanah air, di Arab Saudi, dan saat kepulangan ke tanah air.

\subsection{Klasifikasi}

Berdasarkan Klasifikasi dapat disimpulkan bahwa Redesain Asrama Haji Aceh merupakan tipe asrama haji embarkasi yaitu Asrama haji embarkasi, menyelenggarakan pelayanan akomodasi, konsumsi, dan layanan lain yang diperlukan dalam 
rangka pemberangkatan dan pemulangan bagi jamaah haji.

Asrama haji embarkasi sebagaimana dimaksud pada ayat (2) huruf merupakan unit pelaksana teknis direktorat jenderal penyelenggaraan haji dan umrah.

Asrama haji embarkasi antara sebagaimana dimaksud pada ayat (2) huruf a dan huruf b secara teknis dibina oleh Direktur Pelayanan haji dalam negeri dan secara administratif dibina oleh Sekretaris Direktorat Jenderal Penyelenggaraan haji dan umrah.

\subsection{Struktur Organisasi}

Peraturan menteri agama republik indonesia nomor 44 tahun 2014 tentang organisasi dan tata kerja unit pelaksana teknis asrama haji.

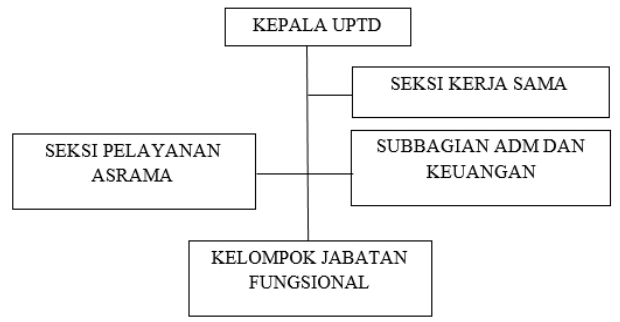

Gambar 2: Struktur Organisasi Asrama Haji Embarkasi

(Sumber: peraturan menteri agama RI nomor 44, 2014)

\section{TEMA PERANCANGAN}

Green Architecture yaitu pendekatan perencanaan arsitektur yang berusaha meminimalisasi berbagai pengaruh membahayakan pada kesehatan manusia dan lingkungan. Konsep green architecture ini memiliki beberapa manfaat diantaranya bangunan lebih tahan lama, mudah dalam perawatan, lebih nyaman ditinggali, serta lebih sehat bagi penghuni. Konsep green architecture memberi kontribusi pada masalah lingkungan.

Green Architecture adalah pendekatan perencanaan Arsitektur yang berusaha meminimalisasi berbagai pengaruh yang bisa membahayakan pada kesehatan manusia dan lingkungan. Konsep Green Architecture Ini memiliki beberapa manfaat diantaranya bangunan lebih tahan lama, hemat energi, perawatan bangunan lebih minimal, lebih nyaman ditinggali, serta lebih sehat bagi penghuni bangunan.

Prinsip-prinsip Green Architecture mencakup 6 hal, yaitu Conserving Energy (Hemat Energi);
Working with Climate (memanfaatkan kondisi dan sumber energi alami); Respect for Site (Menanggapi keadaan tapak pada bangunan); Respect for User (memperhatikan pengguna bangunan); Limitting New Resources (meminimalkan Sumber Daya Baru) serta Holism (menetapkan seluruh prinsip-prinsip secara keseluruhan).

Adapun prinsip-prinsip Green Architecture yang akan diterapkan pada rancangan Asrama Haji Aceh ini adalah 3 aspek, yaitu: Working with Climate (memanfaatkan kondisi dan sumber energi alami), hal ini dilakukan dengan memanfaatkan kondisi alam, iklim dan lingkungan sekitar ke dalam bentuk serta pengoperasian bangunan, misalnya dengan cara memperbanyak bukaan pada bagian selatan untuk memanfaatkan udara segar dari alam sekitar.

Berikutnya adalah prinsip Respect for Site (Menanggapi keadaan tapak pada bangunan), dimana perencanaan mengacu pada interaksi antar bangunan dan tapaknya. Hal ini bertujuan keberadaan bangunan baik dari segi konstruksi, bentuk dan pengoperasiannya tidak merusak lingkungan sekitar.

Selanjutnya adalah Respect for User (memperhatikan pengguna bangunan), yaitu memperhatikan tiap kelompok pemakai dan kebutuhan pemakai dalam perencanaan dan perancangan Asrama Haji Aceh.

\section{ANALISIS PERANCANGAN}

Beberapa analisis yang dilaukan pada perencanaan dan perancangan Asrama Haji Aceh adalah sebagai berikut:

\subsection{Analisis Pemakai dan Kegiatan}

Berdasarkan hasil survei, studi literatur, dan analisa kegiatan maka pemakai pada Asrama Haji Aceh adalah:

\section{Pengelola Asrama Haji Aceh}

Pengelola adalah semua orang yang terlibat dalam menjalankan atau bertanggung jawab terhadap kegiatan administrasi, manajerial dan operasional Asrama Haji Aceh, pengelola terdiri dari:

a. Kepala Unit Pelaksana Teknis Asrama Haji Aceh yang bertugas mengkoordinasikan dan bertanggung jawab atas kegiatan kepegawaian, keuangan, tata usaha dan tata kelola Asrama Haji Aceh.

b. Kasubbag Administrasi dan Keuangan dan staaf yang bertugas mengkoordinasikan dan bertanggung jawab atas segala bagian Administrasi dan Keuangan Asrama Haji Aceh. 
c. Kasi kerja sama yang bertugas untuk mencari instansi pemerintah maupun swasta yang akan dijadikan mitra kerja selama masa operasinal Asrama Haji Aceh.

d. Petugas skretariat dan staaf yang bertugas untuk mengkoordinasikan dan membantu panitia pelaksana haji (PPIH) pada masa operasional Asrama Haji Aceh.

e. Petugas reseptionis dan staaf yang bertugas untuk menerima dan melayani calon haji dan tamu lainnya.

f. Petugas Aula dan staaf yang bertugas untuk bertanggung jawab terhadap segala fasilitas dan kelengkapan aula yang akan dioperasionalkan.

g. Petugas room maid dan staf yang bertugas dan bertanggung jawab atas segala fasilitas dan kelengkapan penginapan perempuan.

h. Petugas room boy dan staf yang bertugas dan bertanggung jawab atas segala fasilitas dan kelengkapan penginapan laki-laki.

i. Petugas cleaning service dan staf yang bertugas dan bertanggung jawab atas kebersihan Asrama Haji selama masa operasional berlangsung untuk kenyamanan pemakai Asrama Haji Aceh.

j. Petugas taman, masjid, keamanan dan teknisi bangunan.

2. Jamaah Haji

Jamaah haji merupakan sekelompok orang

yang akan berangkat ketanah suci untuk menjalankan perintah Allah dan memenuhi rukun islam yang kelima, adapun kegiatan/aktifitas yang dilakukan di Asrama Haji Aceh sebagai berikut : mendaftar dan penyerahan berkas, pembinaan, istirahat/tidur, makan dan minum, dsb.

3. Panitia Pelaksana Ibadah Haji (PPIH)

Merupakan sekelompok orang yang bertanggung jawab atas pelaksanaan dan penerimaan Jamaah Haji yang akan diberangkatkan ketanah suci (diluar staf UPTD), adapun instansi/orang yang terlibat menjadi PPIH sebagai berikut: kepolisian, Bea Cukai, Kesehatan, Transmigrasi, Airport, dsb.

4. Tamu (Pembimbing)

Merupakan orang atau perorangan yang akan memberi bimbingan kepada para Jamaah haji yang akan diberangkatkan ke tanah suci. Adapun tamu/pembimbing yang berhadir pada saat penyelenggaraan penerimaan Jamaah haji sebagai berikut : Kemenag, Walikota, Ka.kanwil, Gubernur, Bupati,dsb.
5. Pengunjung

Merupakan orang atau perorangan yang akan memberi bimbingan kepada para Jamaah haji yang akan diberangkatkan ke tanah suci.

\subsection{Organisasi Ruang}

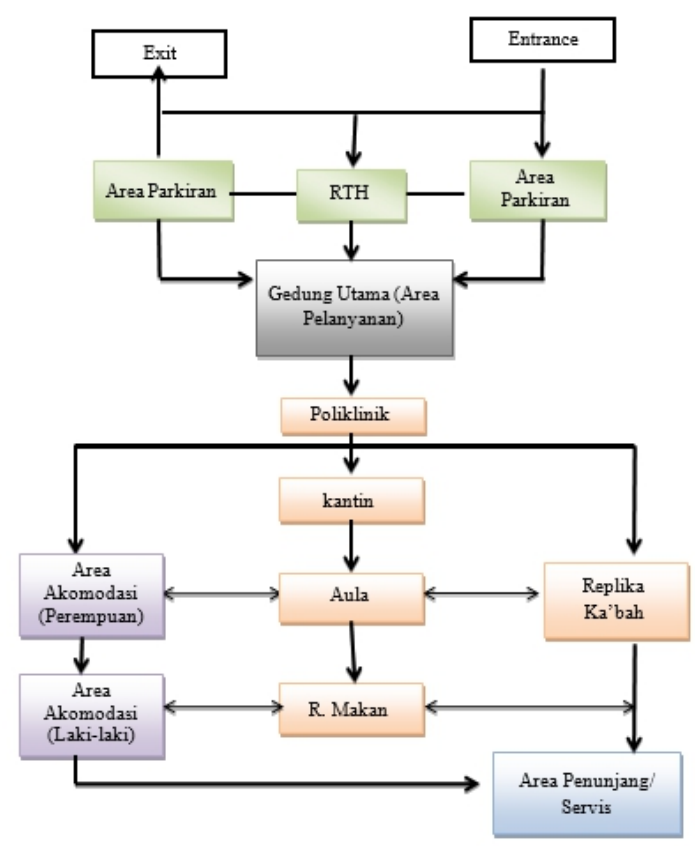

Gambar 3: Organisasi Ruang Maro

(Sumber: analisis, 2019)

\subsection{Besaran Ruang}

Besaran ruang yang disajikan pada tabel 1 dibawah merupakan pembagian berdasaran banyaknya massa bangunan yang dirancang.

\section{Tabel 1: Rekapitulasi Besaran Ruang Asrama} Haji Aceh

\begin{tabular}{clc}
\hline No. & \multicolumn{1}{c}{ Nama Bangunan } & Luas $\left(\mathbf{m}^{2}\right)$ \\
\hline 1 & Gedung utama (Pelayanan) & 1.106 \\
\hline 2 & Asrama Jamaah (2 massa) & 5.568 \\
\hline 3 & Masjid \& Aula & 4.176 \\
\hline 4 & Poliklinik & 1.217 \\
\hline 5 & Ruang Makan & 1.040 \\
\hline 6 & Area Servis & 136 \\
\hline 7 & Area ManasikHaji & 4 \\
\hline & Jumlah Luas Area & 13.247 \\
\hline & Sirulasi 60\% & 7.948 \\
\hline & Total & 21.195 \\
\hline
\end{tabular}

Sumber: analisis (2019) 


\subsection{Analisis Tapak}

Analisis tapak yang dilakukan adalah analisis iklim, analisis view dan analisis vegetasi.

\subsection{Analisis Bangunan}

Analisis bangunan yang dilakukan adalah analisis struktur utama, wujud massa, analisis sirkulasi dalam bangunan dan analisis material.

\section{KONSEP PERANCANGAN}

Konsep Perancangan pada redesain Asrama Haji Aceh beberapa diantaranya adalah sebagai berikut:

\subsection{Konsep Sesuai Tema}

Redesain Asrama Haji Aceh mengangkat tema "Green Architecture", gerakan untuk pelestarian alam dan lingkungan dengan mengutamakan 6 prinsip, diantaranya adalah 3 prinsip yang ditekankan dalam redesain Asrama Haji Aceh.

Adapun kosep "Green Architecture" yang akan diterapkan pada proyek Redesain Asrama Haji Aceh ialah sebagai berikut :

\section{Conserving Energy (Hemat Energi)}

Penerapan konsep hemat energi pada bangunan Asrama Haji Aceh yaitu dengan memanfaatkan kembali sumber daya alam yang tersedia, yaitu pemanfaatan pencahayaan alami dan pemanfaatan kembali air hujan. Pemanfaatan cahaya alami dimaksimalkan agar menminimalisir penggunaan cahaya buatan, dengan begitu akan mengurangi beban energi pada listrik.

Pemanfaatan air hujan dimaksimalkan dengan pengumpulan air hujan (rain water harvesting) dan biofilter yang kemudian digunakan kembali untuk kebutuhan para jamaah, namun mengingat sistem ini belum lazim digunakan di Banda Aceh maka penggunaaan kembali air hujan tersebut masih sebatas kebutuhan wudhu jamaah dan menyiram tanaman.

2. Working with Climate (memanfaatkan kondisi iklim dan lingkungan sekitar)

Bangunan dirancang ulang mengikuti kondisi iklim dan lingkungan sekitar, yaitu menggunakan rancangan bangunan tropis dengan orientasi bangunan menghadap utara dan selatan, memaksimalkan ventilasi udara, penggunaan atap pelana dengan teritisan, serta mengkondisikan langgam arsitektur sesuai dengan tipologi bangunan yaitu bercirikan islam.

\subsection{Konsep Tapak}

Konsep tapak pada lahan dibagimenjadi 2 yaitu konsep penzoningandan pencapaian. Konsep penzoningan didasarkan pada jenis dan kebutuhan kegiatan, persyaratannya dibagi menjadi beberapa zona yaitu zona publik, semi publik, privat dan servis. Konsep pencapaian dapat dicapai melalui jalur utama yaitu JI. T Nyak Arief. Pada pencapaian dalam site terdapat pemisahan pencapaian dengan menggunakan kendaraan dengan pencapaian pejalan kaki.

\subsection{Konsep Vegetasi}

Tata hijau dari vegetasi yang diterapkan pada tapak akan menjadi unsur penting bila perletakannya disesuaikan dengan fungsi dari vegetasi tersebut. Keadaan vegetasi pada sekitar bangunan dapat menurunkan suhu serta dapat mengendalikan penyerapan air hujan sehingga memberikan kenyamanan bagi pengguna bangunan.

Penerapan atau perletakan jenis vegetasi pada rancangan yang diharapkan sesuai dengan tujuan dari jenis tanaman yang dipilih seperti: Palem raja (Roystonea regia), palem putri dan glodok tiang sebagai pohon pengarah. Pucuk merah (Syzygium oleana),bunga kenangan dan perdu sebagai tanaman hias. Pohon tanjung, mahoni, asam jawa dan angsana sebagai filter polusi atau peneduh. Penutup tanah mengunakan rumput manila dan rumput gajah mini.

\subsection{Konsep Parkir}

Perencanaan parkir dipisahkan berdasarkan jenis kendaranannya dan zonasi pemakai. Berdasarkan jenis kendaraan konsep parkir dibagi menjadi area kendaraan roda 2 (dua) dan roda 4 (empat). Berdasarkan zonasi pemakai konsep parkir dibedakan menjadi parkir kendaraan pengelola dan tamu (pembimbing), parkir kendaraan pengunjung dan keluarga jamaah haji yang mengantar atau menjemput, parkir bis jamaah haji dan ambulans, serta parkir untu kendaraan servis.

Parkir kendaraan pengelola dan tamu berada pada area samping bangunan utama dan parkir kendaraan pengunjung terutama untuk keluarga jamaah disediakan pada area depan bangunan yang tidak auh dari bangunan utama. Parkir Bis dan ambulans disediakan di area berdekatan dengan masjid dan bangunan utama, sedangkan parkir servis berdekatan dengan area ruang makan dan asrama. 
Journal of Architecture - University of Muhammadiyah Aceh Vol: $11 \quad$ No: 1 (2021): June

\subsection{Konsep Bentuk Bangunan}

Konsep bentuk bangunan mengikuti bentuk lahan yang ada dengan pengaturan tata letak bangunan yang berorientasi pada utara dan selatan. Hal tersebut dilakukan untuk menghindari penghawaan iklim mikro yang terlalu panas. Bentuk bangunan semuanya berbentuk persegi panjang untuk memaksimalkan penggunaan setiap sudut dan dengan bentuk atap yang menyesuaikan dengan keadaan lingkungan setempat.

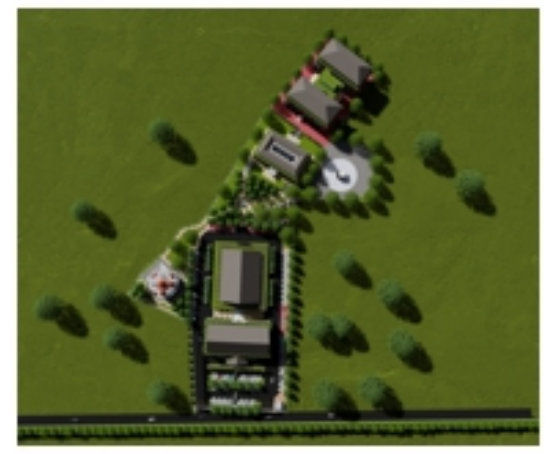

Gambar 4: Site Plan 3

(Sumber: ahmadi, 2019)

\section{HASIL PERANCANGAN}
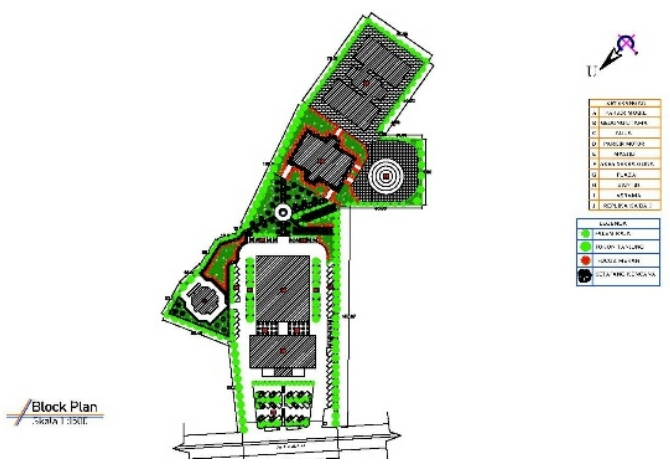

Gambar 5: Site Plan
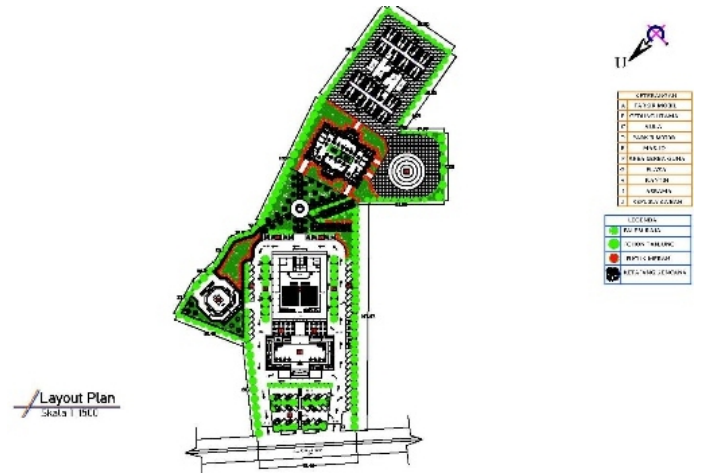

Gambar 6: Layout Plan

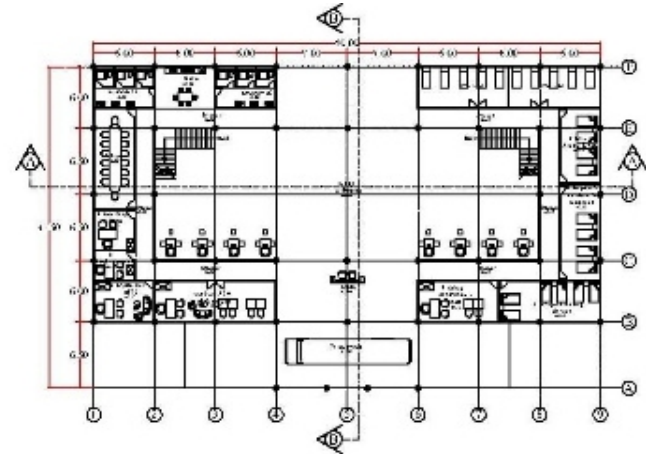

Gambar 7: Denah lantai 1 Gedung Utama

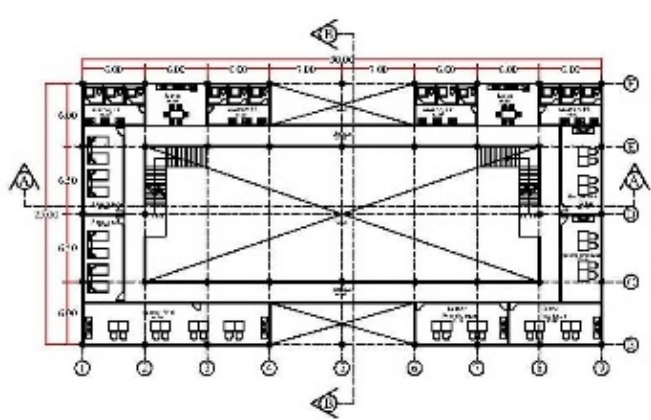

Gambar 8: Denah lantai 2 Gedung Utama

Potongan A-A
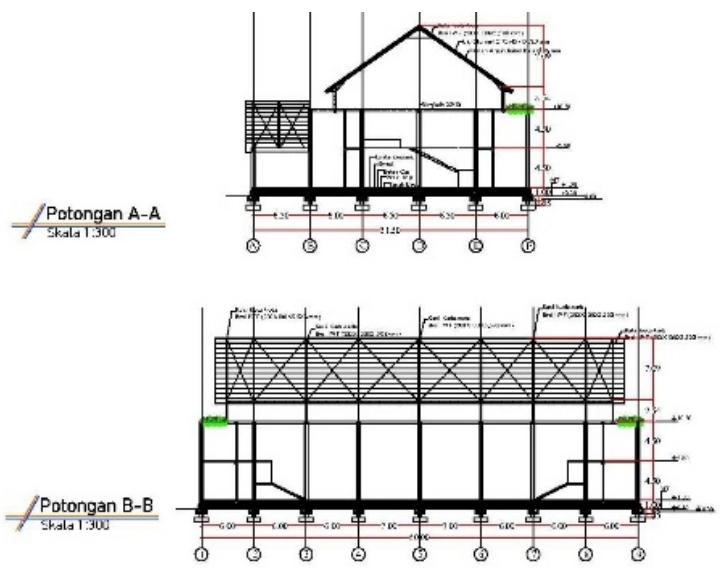

Gambar 9: Potongan A-A dan B-B Gedung Utama
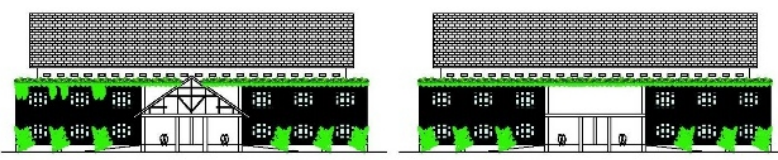

frampar Depan

frampak Belakang
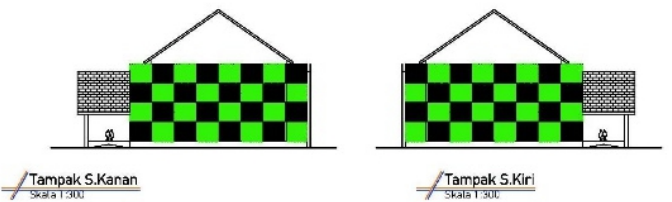

/Tampak S.Kanan

Gambar 10: Tampak Gedung Utama 
Journal of Architecture - University of Muhammadiyah Aceh Vol: 11 |No: 1 (2021): June

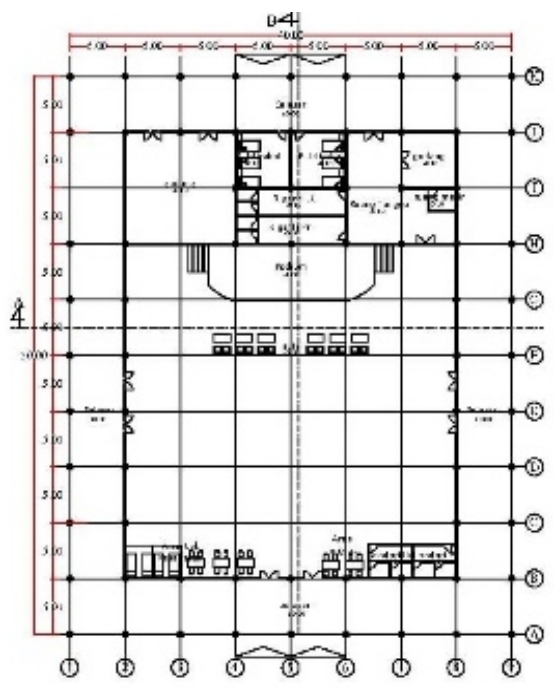

Gambar 11: Denah Aula

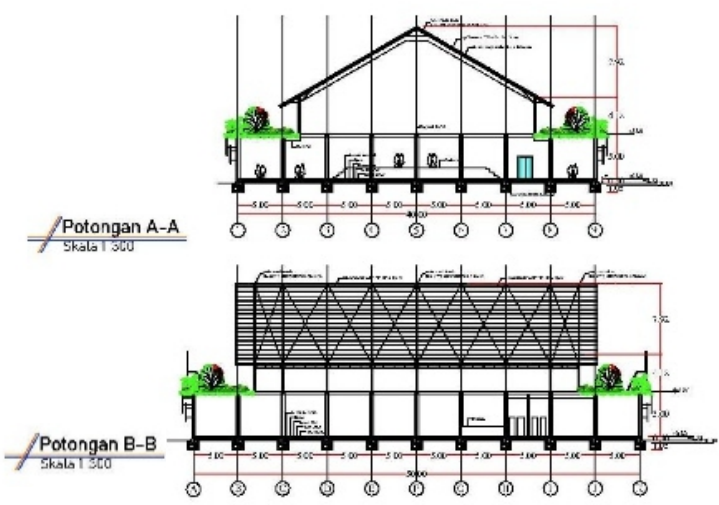

Gambar 12: Potongan A-A dan B-B Aula
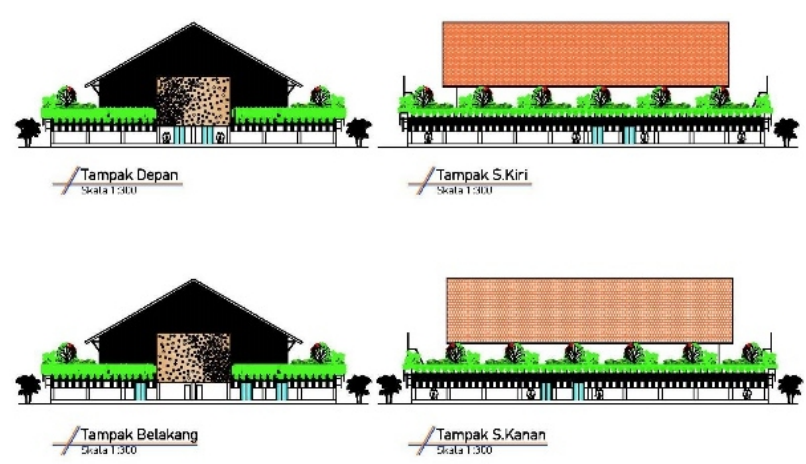

Gambar 13: Tampak Aula
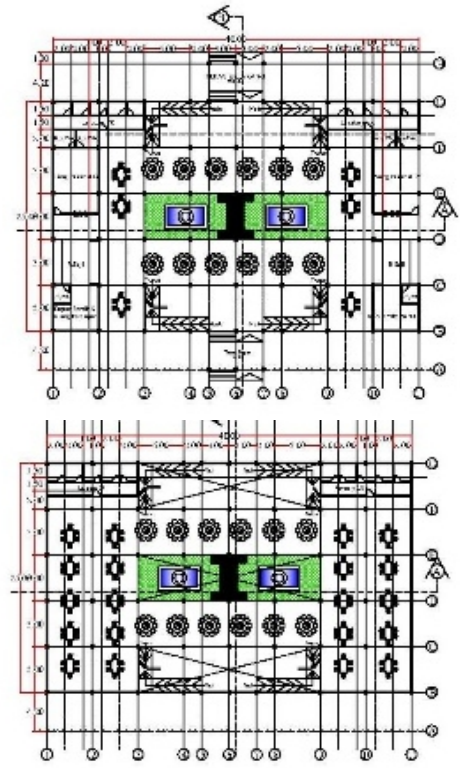

Gambar 14: Denah Lantai 1 dan 2 Ruang Makan

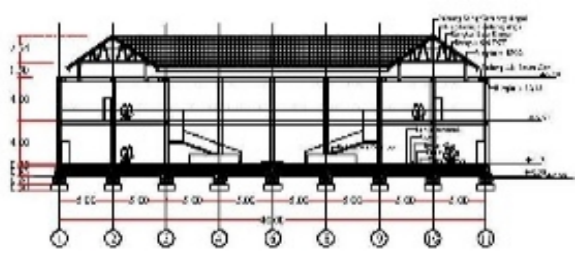

Potongan A-A

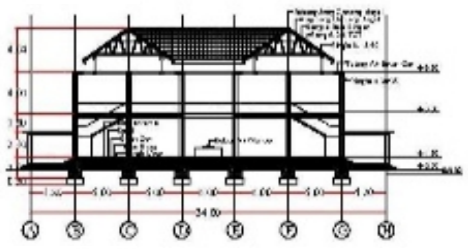

$\int$ Potongan B-B

Gambar 15: Potongan A-A dan B-B Ruang Makan

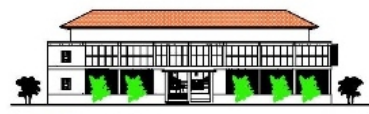

TTampak Depan

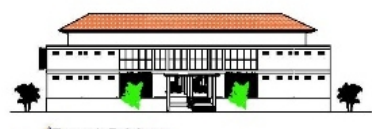

Trampak Belakang

Gambar 16: Tampak Ruang Makan 
Journal of Architecture - University of Muhammadiyah Aceh

Vol: 11 | No: 1 (2021): June
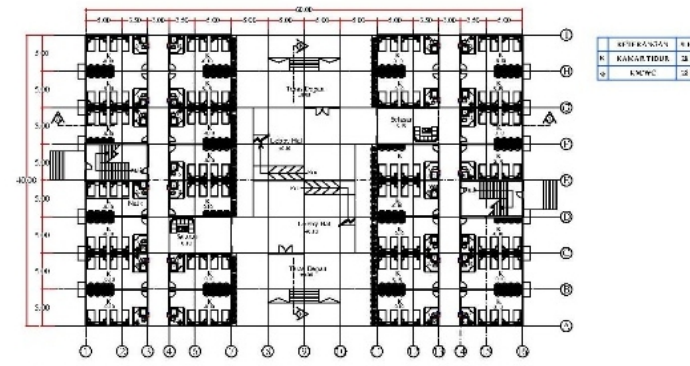

Denah Rencana LT-1

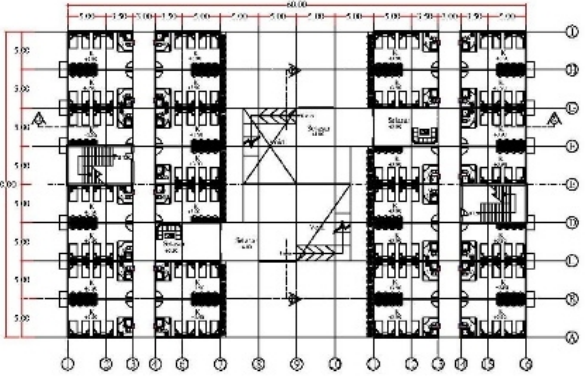

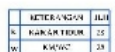
Denah RencanaLT-2

Gambar 17: Denah Asrama Jamaah

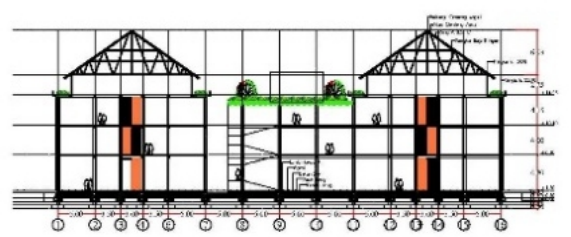

Potongan A-A

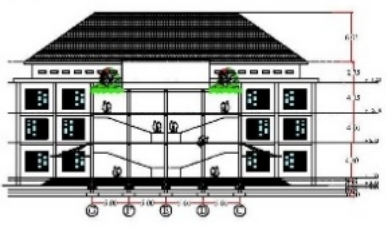

/Potongan B-B

Gambar 18: Potongan Asrama Jamaah

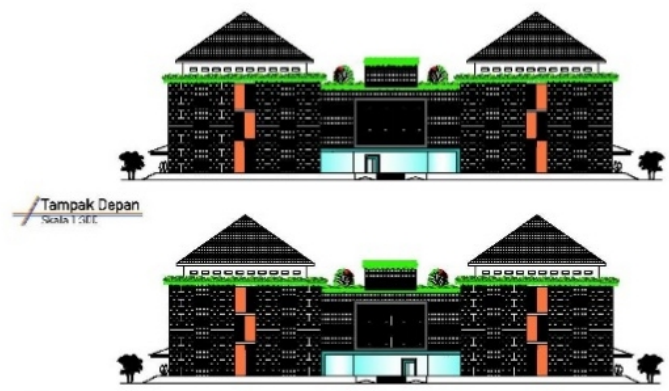

Tampak Bolakano

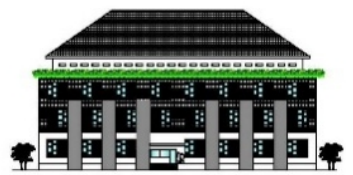

Gambar 19: Tampak Asrama Jamaah
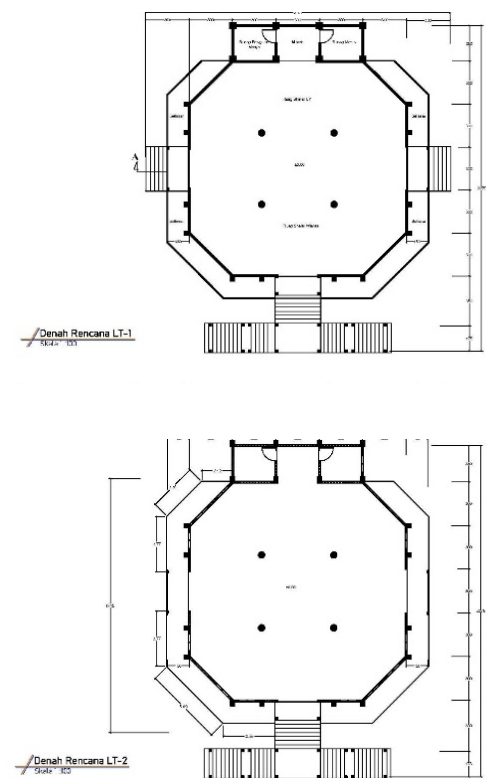

Gambar 20: Denah Lantai 1 dan 2 Masjid
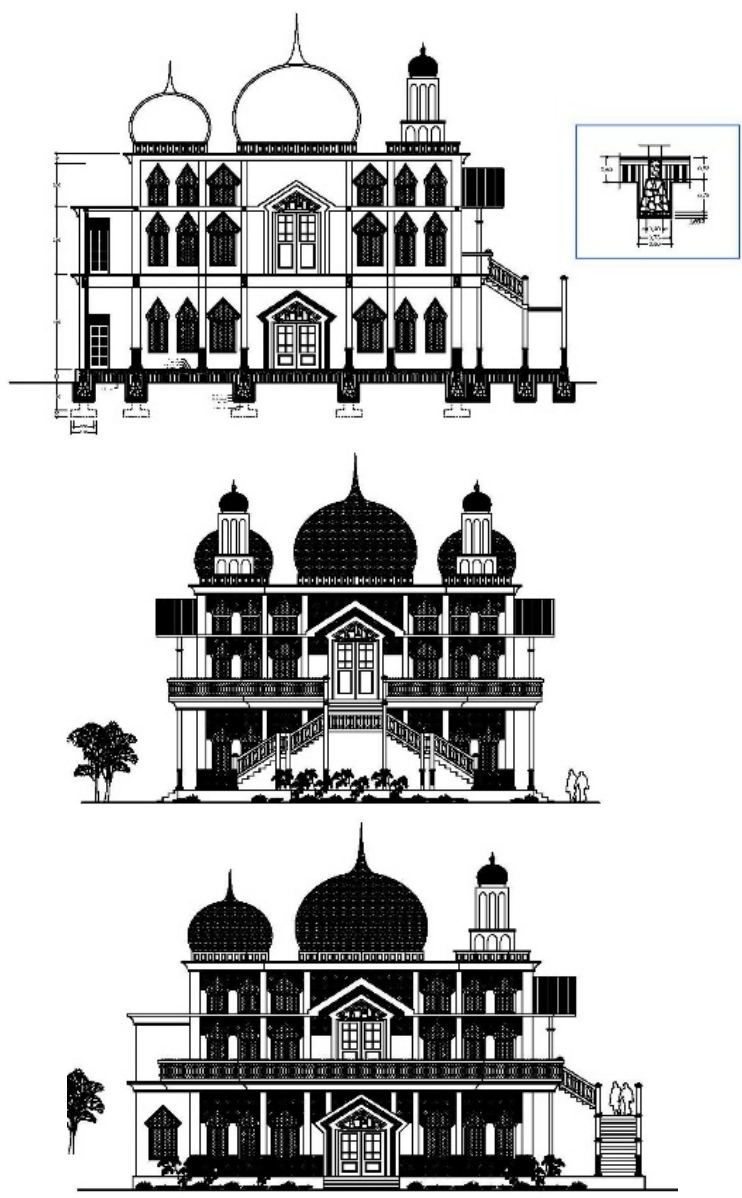

Gambar 21: Potongan dan Tampak Masjid 

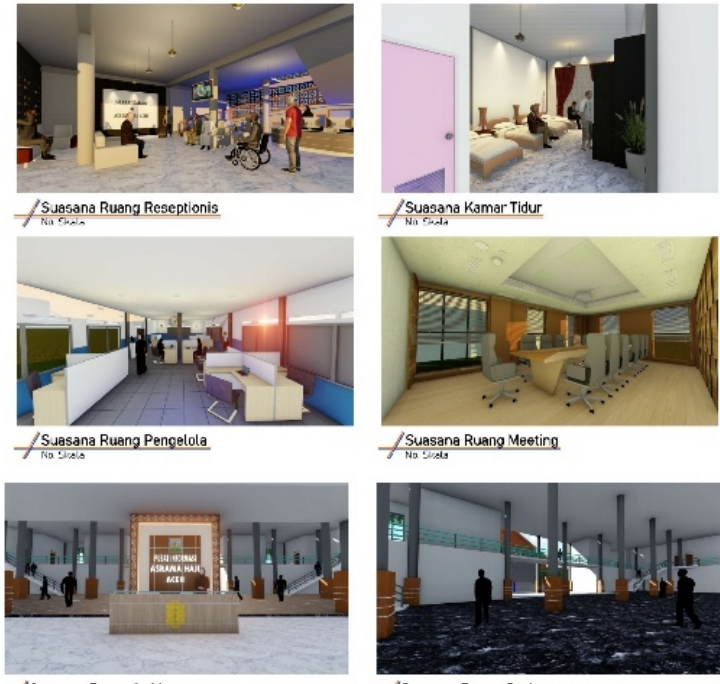

/Suasana Ruang Lobby

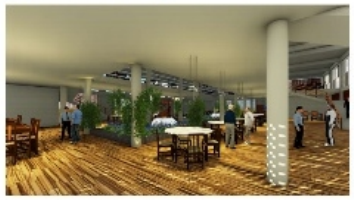

/Suasana Ruang Makan

Gambar 22: Suasana Interior

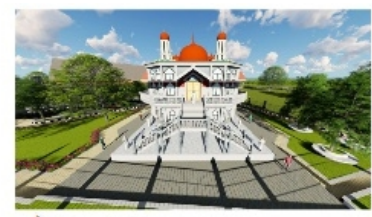

/Suasana Mesjid

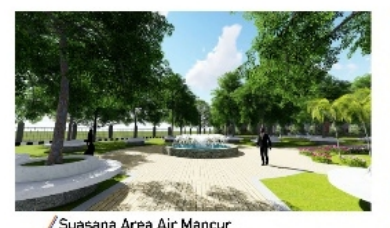

/Suasana Area Air Mancur

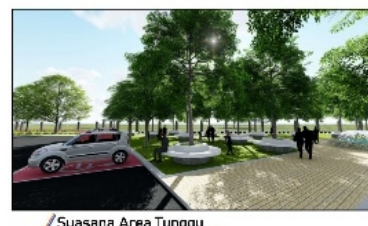

7 Suasana Area Tunggu

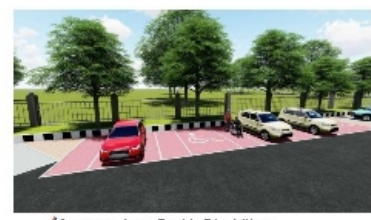

/Suasana Area Parkir Dlsabliltes

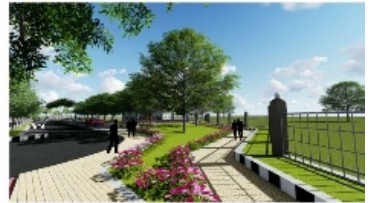

/ Suasana Pedestrian
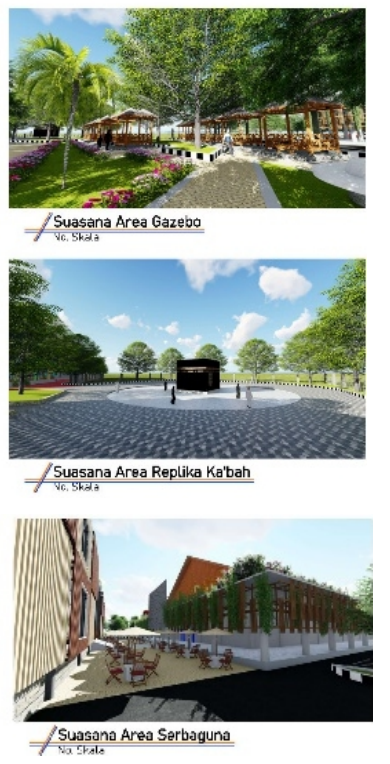

Gambar 23: Suasana Eksterior

\section{DAFTAR PUSTAKA}

Duerk, Donna P. (1993), Architectural Design Programming, New York.

Christina E.Mediastika (2007), Hemat Energi dan Lestari Lingkungan Melalui Bangunan, Yogyakarta.

Snyder, James C (1989), Pengantar Arsitektur, Jakarta.

Wijaya, Y.B Mangun (1992) , Wastu Citra, Jakarta.

http://kbbi.co.id/asrama, (diakses Tgl, 10 Januari 2018; 22:12)

https://haji.kemenag.go.id/v3/blog/ahmad-

ikhwanuddin/dasar-ibadah-haji, (diakses Tgl, 14 Januari 2018; 0:19)

http://alfiykindthovsand.blogspot.co.id/2012/04/haji.h tml, (diakses Tgl, 14 Januari 20178 201;0:29)

Permenag RI no 3 tahun 2013, dalam http://www.biayaumroh.net/info-haji-danumroh/asrama-haji/, (diakses 04 Februari 2018; $0: 50)$

http://asramahajijakarta.com/, (diakses Tgl, 11 Februari 2018; 0:54)

http://adinda-trianda.blogspot.co.id/2012/04/normal0 -false-false-false-en-us-x-none.html, (diakses Tgl, 11 Februari 2018; 22:02)

http://jateng.metrotvnews.com/peristiwa/yNLy01vbjalur-khusus-penyandang-disabilitas-di-terminaltirtonadi-butuh-penyempurnaan, (diakses Tgl, 11 Februari 2018; 22:10)

https://phinemo.com/kota-di-indonesia-yang-ramahuntuk-pejalan-kakil, (diakses Tgl, 11 Juni 2017; 22:22)

http://arsitadulako.blogspot.co.id/2007/05/, (diakses Tgl, 11 Februari 2018; 22:30)

https://haji.kemenag.go.id/v3/, (diakses Tgl, 14 Juni 2018; 0:33)

http://egagoes.blogspot.co.id/, (diakses Tgl, 13 Juli 2018; 20:22)

http://upt-medan.kemenag.go.id/, (diakses Tgl, 14 Juli 2018; 20:45)

https://kemenag.go.id/berita/read/365400/, (diakses Tgl, 14 Juli 2018; 20:45)

https://www2.kemenag.go.id/foto/14303/, (diakses Tgl, 14 Juli 2018; 20:47)

http://jabar.pojoksatu.id/bekasi/2016/07/20/perluasa n-asrama-haji-bekasi-diduga-tanpa-imb/, (diakses Tgl, 14 Juli 2018; 22:30)

http://m.republika.co.id/berita/jurnal-haji/inpicture/16/08/08/obkoq4257-jamaah-kloterpertama-lakukan-registrasi-di-asrama-pondokgede/, (diakses Tgl, 14 Juli 2018; 22:33)

https://indonesiana.tempo.co/read/26401/2014/12/06 /thamrindaffan/sudahkah-anda-wisata-religi-ke- 
Journal of Architecture - University of Muhammadiyah Aceh Vol: 11 | No: 1 (2021): June

asrama-haji-pondok-gede-jakarta-timur/, (diakses Tgl, 14 Juli 2018; 22:34)

http://www.republika.co.id/berita/dunia-islam/umrohhaji/12/10/09/mbmbc6-asrama-haji-pondokgede-dipadati-pengantar-calhaj/, (diakses Tgl, 14 Juli 2018;22:36)

http://m.republika.co.id/berita/jurnal-haji/inpicture/14/08/29/nb2bzc-asrama-haji-pondokgede-bersiap-menyambut-calon-jamaah-haji, (diakses Tgl, 14 Juli 2018;22:36)

http://jateng.tribunnews.com/2016/01/22/selama-didonohudan-eks-gafatar-ditempatkan-di-gedungmadinah-mekkah/, (diakses Tgl, 14 Juli 2018;22:50)

http://asramahajidonohudan.id/room/gedung-arofah/, (diakses Tgl, 14 Juli 2018;22:50)

http://asramahajidonohudan.id/room/ruang-jeddah/, (diakses Tgl, 14 Juli 2018;22:52)

http://asramahajidonohudan.id/room/aulamuzdalifah-pakai-acl, (diakses Tgl, 14 Juli 2018;22:52)

http://asramahajidonohudan.id/room/ruang-kelasgedung-shafal, (diakses Tgl, 14 Juli 2018;22:54) http://asramahajidonohudan.id/room/ruang-lantai-2sekretariat, (diakses Tgl, 14 Juli 2018;22:54) https://www.flickr.com/photos/thebowies/9671377937, (diakses Tgl,15 Juli 2018;22:54)

\section{Kutipan Artikel}

Ahmadi, Aidina (2021) Redesain Asrama Haji Aceh, Tema : Green Architecture, Rumoh, Vol: 11 (1) 1423: Juni. DOI:

http://doi.org/10.37598/rumoh.v11i1.139 